iteration. Optimum relaxation parameters are determined by minimax results for a rational function of the eigenvalues of the matrix components.

On the last morning, under the title "Further Concepts of Iterative Theory and Practice", Dr. Lynn of the National Physical Laboratory discussed quantitative criteria for terminating an iteration automatically, and the organization of block over-relaxation on magnetic tape. Mr. S. Michaelson of the University of Edinburgh spoke on "Choice of Methods in Adverse Problems" and directed attention to the merits of the Bickley-McNamee method and the Schwarz technique for treating problems in L-shaped regions. He also described his experience in solving free-boundary problems in lubrication investigations.
In the afternoon, A. R. Crump of the Nuclear Power Group, Knutsford; Dr. J. C. W. Corcoran of the English Electric Co., Stafford; Dr. R. J. Allwood of English Electric-Leo Computers, Kidsgrove, and J. H. MeDonnell of English Electric Aviation, Warton, deseribed respectively problems arising in the fields of reactor development. electrical network analysis, the analysis of frameworks in civil engineering, and in aeronautical structures. The meeting concluded with a general discussion.

Copies of the pre-circulated notes for the first six lectures are still available, and may be obtained from Dr. D. W. Martin, Mathematies Division, National Physical Laboratory, Teddington, Middlesex, under reference $M a 44 / 027$.

D. W. Martin

\title{
A POLICY FOR DEVELOPMENT AND GROWTH IN SCOTLAND
}

\begin{abstract}
A BROADSHEET entitled A Development Plan for Scotland*, which was written for Political and Economic Planning by G. McRobie, anticipated by about a month the Government's own proposals outlined in the White Paper, Central Scotland-a Programme for Developmint and Growth (H.M.S.O. Cmnd. 2188). Its concise summary of the findings of earlier investigations, such as tho Toothill Inquiry into the Scottish Economy (1961) and that of the National Economic Development Council, Conditions Favourable to Faster Growth, assists the objoctive discussion of the Government's plans. It illustrates the fact that effective regional planning requires decisions about the distribution of populations and investment in basic industries and services which are essentially national in character. It emphasizes, secondly, the fact that within Scotland there are problems of congestion and drift of population, and also needs and resources, which are specific to Scotland, calling for action in harmony with its people and resources, that is, for Scottish decisions. For Britain, it insists, probably more than for any other industrial nation. recent trends in the growth and movement of population have made a comprehensive poliey for regional development a national necossity. The approach and measures suggested in the Broadsheet are, in principle, applicable equally to other parts of Britain.
\end{abstract}

For Scotland, it is suggested that the objective should be to maintain roughly the existing proportion of Britain's population. With a fully employed population this would require a net increase of 150,000 jobs in Scotland over the next six years, of which 100.000 must be created by the expansion of manufacturing industry. With this a policy on distribution of employment and population must be developed, including an acceptable internal structure and a better environment. It is proposed that the whole of Scotland should be treated as a development district, with widely representative District Councils to assess the needs and resources of their districts, set targets for employment and trade, and marshal public opinion in support of district development plans. This need not await the creation of a strong central planning authority covering the whole of Scotland; however, it could help to promote one and supply the information on local needs and resources, local units of administration that the central authority would need, besides an informed and sympathetic body of public opinion, if it is to be effective.

No plans for Scotland can come to anything, however, unless the Scottish economy has an adequate basis in fuel and transport. and at present national policies are not geared to the potential expansion of economic activity in Scotland, which, to attain the objectives visualized in

* Planning, 29, No. 476 (October 14, 1963). A Development Plan for Scotland. Pp. 399-434. (London: Political and Economic Planning, 1963.) 4s. $6 d$. the Broadsheet, must expand at about 5 per cent a year for the next seven or eight years. For transport this means no curtailment of facilities must be permitted until the needs of all localities have been assessed in the light of targets for employment and trade. A. Scottish fuel policy must also be based on a long-term view of require. ments and supplies of energy. It must recognize that by the 1980's Scotland is likely to need energy equivalent to more than 40 million tons of coal, a rapidly growing proportion of which will be in the form of electricity. Decisions as to whether the power stations which will have to be built in the later 1970's are to be coal-or oil-fired cannot long be delayed if Scottish coal resources are to be utilized to the greatest national advantage. The Broadsheet suggests that for a firm basis of future power requirements, Scottish fuel policy should aim at an output of 20-25 million tons of coal annually by the early 1980's.

The Government's development proposals, as the title of the White Paper indicates, are limited to Central Scotland. They comprise an increased annual public service investment programme of $£ 140$ million in which roads and bridges form an important part, and in considering the Beeching proposals for railway closures the Minister of Transport will take account of the present and prospective consequences for the area involved. Three new power stations are to be built, and besides an expanded housing programme, more monoy will bo spent in an attack on squalor and decay in industrial areas, as a prelude to extensive new growth. In the GrangemouthFalkirk area, the Universities of Glasgow and Edinburgh will assist in preparing a comprehensive schome for economic and physical expansion to increase the population by 55,000. The now University of Strathclyde and other developments envisaged by the Robbins Committee are seen as providing a powerful framework for higher technological education and research. The Scottish Development Group will be responsible for phasing and co-ordinating the programme for Central Scotland and extending its surveys to other parts of Scotland, and the Government is prepared to make a financial contribution to the Scottish Council for its work in publicizing Scotland.

Very little was added from the Government sido when the White Paper was debated in the House of Commons on December 3 and 4. Mr. E. Heath, the Secretary of State for Industry, 'Trade and Regional Development and President of the Board of Trade, said that investigations of population and economic prospects over tho next twenty years were already in hand for parts of Scotland outside the central zone, and he had set up an interdepartmental group under Board of Trade chairmanship to survey economic and planning problems in the northwest, which would start from the investigations of landuse on Merseyside and the Manchester conurbation undertaken by the Ministry of Housing and Local Government. The Secretary of State for Scotland, Mr. 
M. Noble, admitted that if Scotland were to overtake the United Kingdom average then its rate of growth would have to exceed 4 per cent, but there was no other indication that the Government's plan might accept the figure suggested in the Political and Economic Planning Broadsheet. Mr. J. Boyd-Carpenter, the Chief Secretary to the Treasury, stressed the significance of university developments, particularly at the University of Strathelyde. In winding up for the Government, Sir Keith Joseph, whilo admitting the need for some machinery at regional level, maintained that this should be achieved by strengthening central Govenment in the regions and not by instituting a new tir $r$ of regionally elected authorities. $\mathrm{He}$ also stressed the great influence of central Government as a customer for Government supplies and its opportunities for creating by fiscal and economic policies a climate of opinion which encouraged private enterprise to expand. In co-operation with private and public enterprise it could also help to ensure that unit costs enable private enterprise to remain competitive.

\section{UNESCO EXPEDITION TO THE LIMESTONE AREAS OF THAILAND}

$\mathrm{U}$ NDER the sponsorship of the Unesco Science Cooperation Office in Djakarta, the fourth Uneseo training expedition was held in Thailand during 1963 .

The expedition formed a continuation of the research work on the flora of limestone areas in tropical south-east Asia, made by three former Unesco expeditions, namely, Java (1960), Borneo (Sarawak, 1961), and Malaya (Ulu Kelantan, 1962) (see Nature, 196, 1169; 1962). Two preliminary excursions were made to the north and northeast of Thailand by Mr. T. Smitinand of the Thai Forest Department (leader) anr? Dr. H. Sleumer of the Rijksherbarium, Leyden (instructor), together with several young Thai forest officers. The first was to the Doi Chiengdao, which, at $2,180 \mathrm{~m}$, is the highest limestone massive of Thailand. The flora of this area, at least as far as the upper, more open vegetation, has so far been fairly well collected; however, as yet, it has not been worked out critically. The second excursion was to the Pha Nok Khao south of Loie, which is a very steep limestone hill, c. $900 \mathrm{~m}$, the flora of which was collected for the first time.

The training expedition proper was held during September 17-October 8. The participants came from Malaya (University of Kuala Lumpur), Singapore (Botanic Garden), the Philippines (Los Baños), Java (Bogor Botanie Garden and Herbarium), South Vietnam (Saigon) and Thailand. The party, consisting of 14 members, first went to Surathani in the south of the Thai Peninsula and from there to a camp set up by the local Forestry Department, situated $44 \mathrm{~km}$ on the road from Surathani to Takuapa in the region of numerous limestone hills. During the expedition, seven of these hills were climbed: Khao Phra Rahu, Khao Lek, Khao Wong, Khao Na Dang, Khao Pak Chawng, Khao Lang Tao and Khao Dai Kuad, ranging in altitude from 180 to about $500 \mathrm{~m}$; each proved to have a few species which were not found on the others, though in general the flora, especially on the lower slopes, was the game.
On September 28 the camp was left and a visit paid to Ko Prap, an island off Surathani. On September 29 the party returned to Bangkok, and on October 1 started from there on the second part of the expedition to Muak Lek, a forestry experimental station to the north of Saraburi, about $130 \mathrm{~km}$ north of Bangkok. From this base the limestone hills Muak Lek, Tap Kwang and Khao Sawng Phi Nawng were climbed; these varied in altitude from 350 to $400 \mathrm{~m}$. The herbarium collections made on limestone hills amounted to a total of 400 specimens, each, so far as was possible, with 5 duplicates (this material will be distributed to the Herbaria of Bangkok (Forest Department), Singapore, Kew, Leyden and Bogor for further investigation). Besides these, living material of about 150 species, especially orchids, was collected to be eultivated and observed in various botanic gardens. In general, it can be said that the vegetation on the limestone hills in the Thai Peninsula near Surathani is remarkably different from that in Ulu Kelantan, Malaya, and is relatively drier. As to the limestone flora in Thailand-where the limestone outerops are found extending from the very south up to the border with Burma in the north in a broken chain over a distance of about $1,600 \mathrm{~km}$-it must be said that the botanical collections made so far are too scarce to give any indication of the areas and routes of migration of the species of this peculiar flora. It is for this reason that the next Unesco Training Expedition will probably be held in Thailand once more, and hence stimulate further research on limestone there. The flora on many of these ancient (mostly Permian) limestone hills is suffering from human inter. ference; this raises an additional urgency for such botanical investigations, which, up until now, have been too fow and far between. A better understanding would also make available the information necessary to present well-founded scientific advice to the Thai Government to consider some of these hills suitable for declaration as nature reserves.
H. SLEUMER

\section{THE ROYAL SOCIETY OF ARTS}

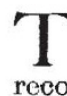
HE tremendous increase in candidates taking tho various examinations of the Royal Society of Arts is recorded in the November issue of its Journal (111, No. 5088; November 1963). Twelve years ago the number of subject-entries in one year was about 130,000 . To-day it is 700,000 and, at the present rate of growth, will excced one million in two or three years' time. Although entries are mainly from candidates at centres in Great Britain and Northern Ireland, there was an increased demand from overseas centres where the numbers went up from 40,271 in 1962 to 53,543 in 1963 . Nigeria is by far the largest of the overseas centres in regard to number of candidates, but the examinations were also in good demand at other centres in West Africa (Gambia, Ghana,
Sierra Leone and West Cameroons). A fuller appreciation of the widespread demand for the Society's examinations can be obtained from the following list of overseas centres in 1963: Aden, Bahamas, Bermuda, British Guiana. British Honduras, Brunei, Cyprus, Ethiopia, Falkland Islands, Fiji, Gibraltar, Jamaica, Kenya, Malta, Mauritius. Nyasaland, Sabah (lately North Borneo). St. Helena, St. Lucia, Southern Rhodesia, Tanganyika, Trinidad, and the British Virgin Islands. In addition. there were a fow centres in foreign countries, mainly for the examinations in English, under the control of officials of the British Embassy or of the British Council.

Particularly pleasing was the increase in demand for the examinations for the Ordinary National Cortificate in 